\title{
Temperature, Duration in Simulated Shipping, and Thermal Acclimatization on the Development of Chilling Injury and Subsequent Flowering of Phalaenopsis
}

\author{
Yin-Tung Wang ${ }^{1}$ \\ Department of Horticultural Sciences, Texas A \& M University System Agricultural Research and \\ Extension Center, 2415 East Highway 83, Weslaco, TX 78596
}

\begin{abstract}
AdDitional INDEX wORDs. low temperature, moth orchid, postharvest handling
Abstract. Bare-root Phalaenopsis Blume orchids are frequently shipped by air freight intercontinentally. It was not known how temperature and duration in shipping affect their subsequent performance during greenhouse production. On 15 Sept., container-grown plants of vegetatively propagated Phalaenopsis (Atien Kaala Group) 'TSC 22' were removed from pots and individually weighed immediately. These bare-root plants were packed in cartons with shredded newspaper and placed in growth chambers at $15,20,25$, or $30{ }^{\circ} \mathrm{C}$ in darkness. After 4 , 7, and 14 days, one-third of the plants were removed from each temperature treatment, weighed, planted in pots, and then placed in a greenhouse. Weight loss increased with increasing air temperature and duration in storage. Chilling injury (CI) was more severe at $15^{\circ} \mathrm{C}$ than $20^{\circ} \mathrm{C}$ storage temperature and was progressively more severe as storage duration increased from 4 to 14 days. Plants had no sign of $\mathrm{CI}$ at $25^{\circ} \mathrm{C}$ or $30^{\circ} \mathrm{C}$ regardless of storage duration. Leaf loss was most severe on plants stored at $15{ }^{\circ} \mathrm{C}$ for 7 days (three leaves) or 14 days (five leaves) or at $30{ }^{\circ} \mathrm{C}$ for 14 days (three leaves). Storing plants 14 days or less between $15^{\circ} \mathrm{C}$ and $25^{\circ} \mathrm{C}$ did not affect the time of spiking (emergence of the flowering shoot), but at $30{ }^{\circ} \mathrm{C}$, spiking was delayed by 5 to 8 days regardless of the duration. Storage resulted in reduced flower count, but not flower size, regardless of temperature and duration. In a second experiment, potted Phalaenopsis plants of the same clone were thermal-acclimatized in growth chambers in mid-September for 10 days at $25^{\circ} \mathrm{C}$ followed by another 10 days at $20^{\circ} \mathrm{C}$ before being stored in pots or bare-root at $15{ }^{\circ} \mathrm{C}, 20^{\circ} \mathrm{C}, 25^{\circ} \mathrm{C}$, or $30^{\circ} \mathrm{C}$ for 10 days. Thermal acclimatizing at $25^{\circ} \mathrm{C}$ and $20^{\circ} \mathrm{C}$ reduced the severity of $\mathrm{CI}$ and leaf loss after being stored for 10 days at $15^{\circ} \mathrm{C}$ either bare-root or in pots, but did not reduce leaf loss resulting from heat at $30{ }^{\circ} \mathrm{C}$. Repotting or storing bare-root plants did not affect spiking or flowering date under otherwise similar conditions. Nondisturbed plants in pots stored at temperatures between $20^{\circ} \mathrm{C}$ and $30^{\circ} \mathrm{C}$ for $10 \mathrm{~d}$ had higher flower count as compared with bare-root plants that were similarly stored. Spiking of nonacclimatized, bare-root plants was delayed after 10 days at either storage temperature, whereas flowering was delayed by $15^{\circ} \mathrm{C}$ and $30^{\circ} \mathrm{C}$ only. Bare-root Phalaenopsis orchids should be shipped near $25^{\circ} \mathrm{C}$ during the warm period of the year and between $25^{\circ} \mathrm{C}$ and $15^{\circ} \mathrm{C}$ in the late fall through early spring to avoid $\mathrm{CI}$ or heat stress.
\end{abstract}

Traditionally, most orchid growers bred and raised orchids from seed for sale. All orchids grow slowly compared with other potted flowering plants, requiring several years before seedling or cloned plants are capable of producing flowers. This long production time drastically increases the cost and hence market price.

In recent years, the production of potted flowering orchids has increased markedly. The wholesale value of potted orchids reached an all time high of $\$ 144$ million in 2005 (U.S. Dept. of Agr., 2006), an 11.5\% increase from 2004, and second only to poinsettia (Euphorbia pulcherrima Willd. Ex. Klotzsch). Although the orchid market has not been saturated, competition on the marketplace has become more intense because of increased production. At the same time, many operations specializing in raising orchids from seed or tissue culture have

Received for publication 26 June 2006. Accepted for publication 4 Jan. 2007. The cloned Phalaenopsis orchids were personal gifts from Taiwan Sugar Corporation, Taipei, Taiwan, P.R. China. The assistance of Maria Elizabeth Cardenas Cerda (on sabbatical leave from the University of Nuevo Leon, Nuevo Leon, Mexico), Aynne Garcia, Julio Perez, and Esquil Perez is greatly appreciated.

${ }^{1}$ Professor of Floriculture and Plant Physiology. E-mail: yt-wang@tamu.edu. been established overseas to provide orchids of various ages and sizes to downstream orchid producers.

In the United States, a common production strategy is to import nonflowering orchids from tropical climates and then induce flowering. Nearly all of these large suppliers are overseas and bare-root orchids are frequently sent to the United States by air freight. While in transit and in warehouses, millions of orchids, mostly Phalaenopsis hybrids, are exposed to a wide range of temperatures. Leaf temperature lower than $10{ }^{\circ} \mathrm{C}$ had been recorded during transit (Y.T. Wang, unpublished data). Leaves sometimes turn yellow and fall off after planting and after being placed in greenhouses. Many of these plants become unmarketable and result in losses to growers.

Importation of nursery-grown orchid species and hybrids requires special permits and plants are inspected at a designated port of entry. Commonly, 3 to $7 \mathrm{~d}$ elapse between the time plants are shipped out of a nursery and being received by growers in the United States. However, it is not unusual for plants to be held at inspection stations for 1 week or more because of improper documentation or other delays. During this period, plants may be exposed to a wide range of temperatures depending on how they are handled and stored. 
Tropical species can experience chilling injury (CI) by relatively cool air for short durations. For instance, Sansevieria trifasciata (de Wildm.) N. E. Br., Scindapsus pictus Hassk., Aphelandra squarrosa Ness., and Maranta leuconeura E. Moor. were injured by temperatures below $8{ }^{\circ} \mathrm{C}$ (McConnell et al., 1982; McWilliams and Smith, 1978). Dracaena sanderana Hort. Sander ex. M.T. and Spathphyllum Schott cv. Clevelandii were injured after exposure to $10{ }^{\circ} \mathrm{C}$ for $1 \mathrm{~d}$ or $13{ }^{\circ} \mathrm{C}$ for $2 \mathrm{~d}$ (Marousky, 1980). Clerodendrum speciosum Dombr. grown for $3 \mathrm{~d}$ or longer at day temperatures of $17^{\circ} \mathrm{C}$ to $22^{\circ} \mathrm{C}$, instead of $32{ }^{\circ} \mathrm{C}$, were preconditioned to withstand chilling at $2{ }^{\circ} \mathrm{C}$ (Tamari et al., 1992).

High temperatures during shipping can also injure tropical species. Unrooted cuttings of Codiaeum variegatum Blume cv. Craigii that were stored at $30{ }^{\circ} \mathrm{C}$ for $15 \mathrm{~d}$ lost $55 \%$ of their leaves as opposed to $7 \%$ at $20{ }^{\circ} \mathrm{C}$ or $15{ }^{\circ} \mathrm{C}$ (Wang, 1987). Su et al. (2001) studied the effect of exposing bare-root Phalaenopsis equestris (Schauer) Rchb.f. plants to $25^{\circ} \mathrm{C}$ or $35^{\circ} \mathrm{C}$ for up to $30 \mathrm{~d}$ on the photosynthetic behavior of leaves and roots at $70 \%$ or $10 \%$ relative humidity. However, in their study, the small plants were not packed in containers to simulate the actual shipping conditions but were directly exposed to the moving air in growth chambers, subjecting them to unusually adverse conditions. As a result, plants rapidly desiccated.

Phalaenopsis species are native to tropical and subtropical climates (Christensen, 2001) and may not tolerate high or low temperatures, particularly when shipped bare-root. Spotting and pitting were induced on Phalaenopsis orchid leaves by exposure to $2^{\circ} \mathrm{C}, 4^{\circ} \mathrm{C}$, or $7^{\circ} \mathrm{C}$ for $8 \mathrm{~h}$ or less (McConnell and Sheehan, 1978). One or more layers of mesophyll cells collapsed and formed an internal horizontal necrotic layer. The optimal temperature for shipping the Phalaenopsis orchids across continents for several days is not known. In addition, there has been no documentation on how transporting bare-root Phalaenopsis would affect its performance after shipping and replanting.

The objectives of this study were to 1) determine the impact of a range of temperature and duration during simulated shipping and 2) characterize the effect of thermal acclimatizing plants before simulated shipping on the morphology and subsequent greenhouse performance of a cloned Phalaenopsis hybrid. Also, the responses of bare-root and undisturbed pot plants to thermal acclimatization and shipping temperature were compared after simulated shipping.

\section{Materials and Methods}

Plant materials. A white-flowered clone Phalaenopsis (Atien Kaala Group) 'TSC 22' was used in this study. Plants $15 \mathrm{~cm}$ in leaf spread were potted in round plastic pots $(11.4 \mathrm{~cm}$ diameter, $0.6 \mathrm{~L}$ volume) on 23 June in a medium consisting of $70 \%$ fine-grade Douglas Fir [Pseudotsuga menziesii var. menziesii (Mirb.) Franco] bark and 30\% coarse Canadian sphagnum peat. Plants were irrigated with reverse osmosis water containing of $1 \mathrm{~g} \cdot \mathrm{L}^{-1} 20 \mathrm{~N}-8.6 \mathrm{P}-16.6 \mathrm{~K}$ soluble fertilizer (Scotts, Marysville, Ohio). Plants received $\approx 12 \%$ full sun light, providing a maximum photosynthetic photon flux $(P P F)$ of $300 \mu \mathrm{mol} \cdot \mathrm{m}^{-2} \cdot \mathrm{s}^{-1}$ in the summer and $160 \mu \mathrm{mol} \cdot \mathrm{m}^{-2} \cdot \mathrm{s}^{-1}$ in the winter when measured at solar noon. Greenhouse air temperature ranged between $34^{\circ} \mathrm{C}$ in the summer and $17^{\circ} \mathrm{C}$ in the winter. All plants were repotted into $15-\mathrm{cm}$-diameter pots
(1.75 L volume) in March the next year in the same medium as a result of their increased size.

EXPt. 1. Effects of temperature and duration. On 15 Sept., plants were removed from pots and cleaned of potting medium. The bare-root plants were individually weighed and 30 were placed in each of four cartons with shredded newspaper to simulate international shipping conditions. Cartons were placed in dark growth chambers (model I-35LL; Percival Scientific, Boone, Iowa) maintained at a constant $15^{\circ} \mathrm{C}, 20^{\circ} \mathrm{C}$, $25^{\circ} \mathrm{C}$, or $30^{\circ} \mathrm{C}$. After 4,7 , or $14 \mathrm{~d}, 10$ plants were removed randomly from each temperature treatment, weighed, planted in 15-cm-diameter pots with fresh medium, and returned to the greenhouse and cultured as described previously for observation. Weight loss during simulated shipping was calculated from the original and final weights. Degree of CI was evaluated $10 \mathrm{~d}$ after replanting with the following scale: $0=$ no injury; $1=$ a hint of light green, marketable; $2=$ small yellow areas, marketability questionable; 3 = obvious yellow areas, unmarketable; 4 = extensive injury; and $5=$ severe injury. Leaf loss, date of spiking, flowering date, and flower number and size were recorded for every plant.

Plants were arranged in a randomized complete block design after being returned to a greenhouse. A single plant in a pot consisted of a replication and treatments were each replicated 10 times. Data within each storage duration were subjected to analysis of variance (ANOVA) (SAS Institute, Cary, N.C.) and Duncan's multiple range test was used for separating the means of temperature effects when $\mathrm{F}$ values were significant at $P \leq$ 0.01 . The significance of duration effect was determined.

EXPT. 2. EFFECTS OF THERMAL ACCLIMATIZATION ON BARE-ROOT AND UNDISTURBED PLANTS. On 15 Sept., 64 orchids of the same clone in 15-cm-diameter pots were selected from a greenhouse and 16 were placed in each of four chambers maintained at $25^{\circ} \mathrm{C}$ with a $P P F$ of $60 \mu \mathrm{mol} \cdot \mathrm{m}^{-2} \cdot \mathrm{s}^{-1}$ from cool-white florescent tubes for $12 \mathrm{~h}$ daily. Plants were watered as necessary. After 10 $\mathrm{d}$, air temperature in these chambers was dropped to $20{ }^{\circ} \mathrm{C}$ and remained as such for an additional $10 \mathrm{~d}$. This was to simulate the lower greenhouse temperatures in late fall and early winter. Then, the light was shut off and air temperatures were changed to $15^{\circ} \mathrm{C}, 20^{\circ} \mathrm{C}, 25^{\circ} \mathrm{C}$, or $30^{\circ} \mathrm{C}$. In each chamber, eight plants were removed from the pots and packed in a carton with shredded newspaper and the other eight remained undisturbed.

The daily high and low temperatures in the greenhouse changed very little during the 20 -d thermal acclimatization period. At the end of this period, an additional 64 plants were taken directly from the same greenhouse and 16 were placed in each chamber. Eight of these nonacclimatized orchids in each chamber were packed bare-root in the carton while the remaining eight stayed in pots. All these orchids were held in chambers at various temperatures for an additional $10 \mathrm{~d}$ before being moved back to a greenhouse as previously described. Bare-root plants were replanted.

At the end of this $30-\mathrm{d}$ period, eight plants that remained in the greenhouse were taken from their pots, medium removed, and immediately planted back in pots for use as the greenhouse bare-root control. An additional eight undisturbed plants were used as greenhouse pot control. Leaf loss, dates of spiking and flowering, and flower number and size were recorded.

Plants, after being moved back to a greenhouse, were arranged in a randomized complete block design with eight single-plant replications. Data within each storage temperature were subjected to ANOVA (SAS Institute) and Duncan's 
multiple range test was used for separating the treatment means when $\mathrm{F}$ values were significant at $P \leq 0.01$.

\section{Results}

Expt. 1. EfFects of Temperature AND duration. Weight loss was mainly the result of dehydration of the plants. The severity of dehydration increased with longer durations in storage and was most severe after storing for $14 \mathrm{~d}$ at $25{ }^{\circ} \mathrm{C}$ (37 g or $20 \%$ of the original fresh wt) or $30{ }^{\circ} \mathrm{C} \mathrm{(48} \mathrm{g} \mathrm{or} 27 \%$ of the original fresh wt). Weight loss was similar for plants stored at $15^{\circ} \mathrm{C}$ or $20^{\circ} \mathrm{C}$ and increased as temperature increased from $20{ }^{\circ} \mathrm{C}$ to $30{ }^{\circ} \mathrm{C}$ (Table 1$)$.

No visible symptoms of injury were observed on removal of plants from chambers after 4 or $7 \mathrm{~d}$ regardless of storage temperature. After $14 \mathrm{~d}$, however, some of the leaves on plants that were kept at $30^{\circ} \mathrm{C}$ had yellow areas and those at $15^{\circ} \mathrm{C}$ had some small, translucent spots.

Symptoms of CI developed after a few days in a greenhouse. Plants that were stored for $4 \mathrm{~d}$ at $20{ }^{\circ} \mathrm{C}$ or $15^{\circ} \mathrm{C}$ developed two large yellow spots at the base of the top leaves, one on either side of the midrib. The degree of CI was more severe on plants that were stored for $7 \mathrm{~d}$ at $20{ }^{\circ} \mathrm{C}$ or $15{ }^{\circ} \mathrm{C}$ (Fig. 1). Leaf abscission was most severe for plants stored for $7 \mathrm{~d}$ at $15^{\circ} \mathrm{C}$ or $14 \mathrm{~d}$ at either $15^{\circ} \mathrm{C}$ or $30^{\circ} \mathrm{C}$ (Table 1 ).

Spiking and flowering dates were delayed in plants that were stored at $15{ }^{\circ} \mathrm{C}$ for $14 \mathrm{~d}$ (Table 1). Storage for $7 \mathrm{~d}$ at $15^{\circ} \mathrm{C}$ or $30{ }^{\circ} \mathrm{C}$ or $14 \mathrm{~d}$ at $15^{\circ} \mathrm{C}, 20^{\circ} \mathrm{C}$, or $30^{\circ} \mathrm{C}$ resulted in reduced flower count. Flowers size, however, was unaffected by either temperature or duration in storage.

EXPT. 2. EFFECTS OF THERMAL ACCLIMATIZATION ON BARE-ROOT AND UNDISTURBED PLANTS. Thermal-acclimatizing plants at $25^{\circ} \mathrm{C}$ for $10 \mathrm{~d}$ followed by another $10 \mathrm{~d}$ at $20^{\circ} \mathrm{C}$ prepared plants for safe low-temperature storage. Nonacclimatized plants being exposed to $15^{\circ} \mathrm{C}$ for $10 \mathrm{~d}$ had much higher leaf drop (3.0) than acclimatized plants (1.0; Table 2). Thermal acclimatization reduced the degree of CI (leaf loss) after being stored for 10 $\mathrm{d}$ at $15^{\circ} \mathrm{C}$ either bare-root or in pots. Plants, either bare-root or in pots, which were stored at $20^{\circ} \mathrm{C}$ or $25^{\circ} \mathrm{C}$ for $10 \mathrm{~d}$, whether acclimatized or not, did not have abnormal leaf drop or other symptoms of CI. Storing at $30{ }^{\circ} \mathrm{C}$ resulted in severe leaf yellowing and abscission, possibly as a result of heat stress.

Spiking dates were delayed by storing nonacclimatized plants at $15{ }^{\circ} \mathrm{C}$ or $30^{\circ} \mathrm{C}$ regardless of whether plants remained in the pot or bare-root during simulated shipping (Table 2). However, acclimatized plants that were stored at $15^{\circ} \mathrm{C}$ or $30^{\circ} \mathrm{C}$ had similar spiking dates as the greenhouse controls. Nonacclimatized plants stored bare-root at $20{ }^{\circ} \mathrm{C}$ or $25{ }^{\circ} \mathrm{C}$ had delayed spiking (Table 2). Flowering date was delayed only in nonacclimatized plants that were stored at $15^{\circ} \mathrm{C}$ or $30^{\circ} \mathrm{C}$ for $10 \mathrm{~d}$.

Spike (inflorescence) number was lower in nonacclimatized plants that were stored at $15{ }^{\circ} \mathrm{C}$ as well as in bare-root acclimatized plants that were stored at any temperature (Table 2). Nonacclimatized plants in pots and stored at temperatures between $20{ }^{\circ} \mathrm{C}$ and $30{ }^{\circ} \mathrm{C}$ for $10 \mathrm{~d}$ produced a higher flower count compared with bare-root storage under similar conditions (Table 2). Repotting the greenhouse control plants resulted in smaller flowers. However, thermal acclimatization and storage temperature had no effect on flower size.

\section{Discussion}

Loss of water from stored horticultural crops is one of the major concerns and causes of deterioration during storage or shipping. Dehydration increases with temperature and is greater in light than in darkness when the relative humidity remains similar (Su et al., 2001; Wells, 1962). The air in the chambers used in this study was continuously circulated and air humidity was not regulated. As a result, it may have caused faster water

Table 1. Effects of duration in simulated shipping at one of four temperatures on plant quality and subsequent greenhouse performance of Phalaenopsis (Atien Kaala Group) 'TSC 22' (Expt. 1).

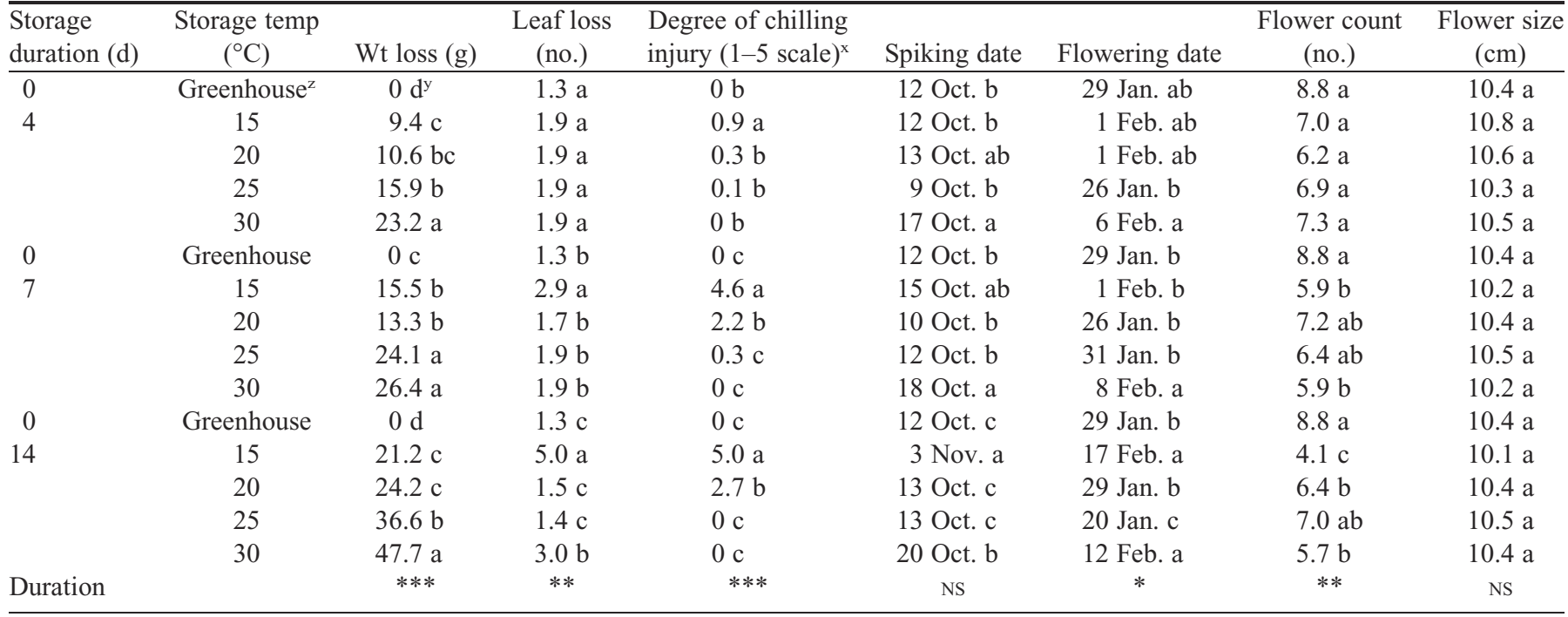

zPlants that remained in a greenhouse.

'Duncan's multiple range test was used for mean separation at $P \leq 0.05$.

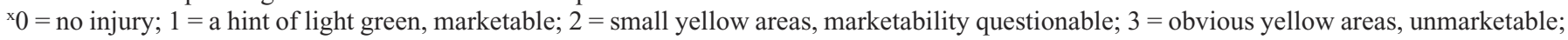
4 = extensive injury; 5 = severe injury.

Ns, ${ }^{*},{ }^{* *},{ }^{* * *}$ Nonsignificant or significant at $P \leq 0.05,0.01$, or 0.001 , respectively. 


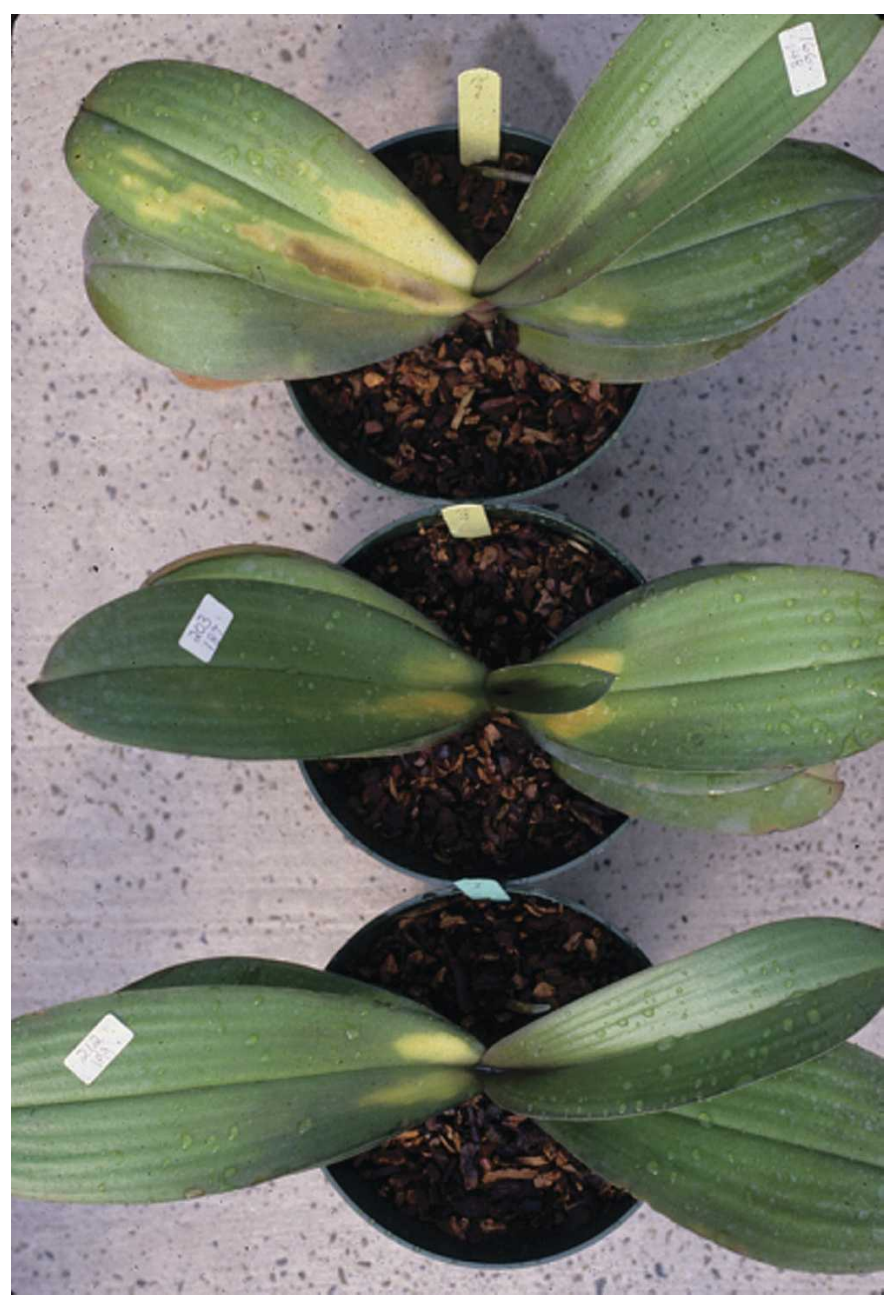

Fig. 1. Phalaenopsis plants after being stored bare-root at $15^{\circ} \mathrm{C}$ for 7 (top) or 4 (middle) $\mathrm{d}$ or at $20{ }^{\circ} \mathrm{C}$ for $4 \mathrm{~d}$ (bottom) and then potted and placed in a greenhouse (Expt. 1). The yellow patches on leaves were symptoms of chilling injury.

loss than similarly packaged plants under commercial shipping conditions in which boxes are packed tightly and air circulation is minimal or none at all.

Although Phalaenopsis orchids are epiphytic plants, they do not have a thick waxy layer on their leaves (Lee and Lee, 1991) to prevent rapid water loss after removal from pots. $\mathrm{Su}$ et al. (2001) found that bare-root $P$. equestris plants lost $40 \%$ of their fresh weight after $15 \mathrm{~d}$ at $35^{\circ} \mathrm{C}$. Bare-root $P$. equestris plants exposed to $25{ }^{\circ} \mathrm{C}$ circulating air with $70 \%$ relative humidity in growth chambers lost $20 \%$ and $10 \%$ fresh weight after $15 \mathrm{~d}$ in light or darkness, respectively (Su et al., 2001). Neither quantum efficiency nor electron transport rate was affected in plants losing $30 \%$ of fresh weight after $30 \mathrm{~d}$ of storage at $25{ }^{\circ} \mathrm{C}$. However, subsequent vegetative performance and flowering were not determined. In contrast, Ota et al. (1991) found that withholding water from Phalaenopsis for a few days reduced $\mathrm{CO}_{2}$ uptake by the leaves. In the current study, plants that were stored at $30{ }^{\circ} \mathrm{C}$ for 7 or $14 \mathrm{~d}$ lost $26 \mathrm{~g}$ $(17 \%)$ and $48 \mathrm{~g}(27 \%)$ of their fresh weight, respectively (Table 1), which resulted in reduced flower count, severe leaf loss, or both, possibly the result of heat stress. Although plants stored at $25^{\circ} \mathrm{C}$ for $14 \mathrm{~d}$ lost $37 \mathrm{~g}(20 \%)$ of fresh weight, they lost a similar number of leaves and produced an acceptable number of flowers compared with the controls. These results suggest that when stored at optimal temperatures, plants could lose one-fifth of their fresh weight without affecting their subsequent performance.

Subtropical and tropical species such as D. sanderana and Spathphyllum Schhott. 'Clevelandii' experience injury after only $1 \mathrm{~d}$ at $10{ }^{\circ} \mathrm{C}$ or $2 \mathrm{~d}$ at $13^{\circ} \mathrm{C}$ (Marousky, 1980). Aglaonema Schott. 'Siver Queen' plants have CI after $10 \mathrm{~h}$ at $21{ }^{\circ} \mathrm{C}$ (Fooshee and McConnell, 1987). Sansevieria trifasciata (de Wildm.) N. E. Br. 'Laurentii' plants receiving high rates of nitrogen fertilizer, which is associated with low $\mathrm{Ca}$ in the tissues, are more sensitive to chilling temperatures (Conover and Poole, 1976; Marlatt, 1974). Most commercial hybrids of Phalaenopsis are bred from subtropical or tropical species (Christensen, 2001). These hybrids grow and flower best at temperatures between $25^{\circ} \mathrm{C}$ and $30^{\circ} \mathrm{C}$ (Lee and Lin, 1984; Lee and Wang, 1997; Lin and Lee, 1988) when fertilized heavily (Wang, 1994, 1996) under optimal lighting (Wang, 2001). Orchids used in this study received a high rate of fertilization $\left(1 \mathrm{~g} \cdot \mathrm{L}^{-1} 20 \mathrm{~N}-4.6 \mathrm{P}-16.6 \mathrm{~K}\right)$ in nearly pure water that resulted in an average leaf $\mathrm{Ca}$ level of $1.5 \%$ on a dry weight basis, which was lower than that found in another study (over 2.5\%; Wang, 1998). It is unclear if application of supplemental Ca during production to raise tissue $\mathrm{Ca}$ level would increase plants' tolerance to low temperatures.

Leaves of crops that are sensitive to chilling temperatures develop chlorotic spots when cooled quickly and then warmed in a short period of time (Treshaw, 1970). In Expt. 1, plants were taken from a greenhouse, where daytime highs were $31^{\circ} \mathrm{C}$ to $33{ }^{\circ} \mathrm{C}$ and nighttime lows were $24{ }^{\circ} \mathrm{C}$ to $26^{\circ} \mathrm{C}$, and placed directly into various temperature treatments. This sudden and steep change in temperature may have been the cause of CI at $20{ }^{\circ} \mathrm{C}$ and $15^{\circ} \mathrm{C}$. This is further supported by the fact that, in Expt. 2, thermal-acclimatizing plants at $25^{\circ} \mathrm{C}$ and $20^{\circ} \mathrm{C}$ before exposing them to $20^{\circ} \mathrm{C}$ or $15^{\circ} \mathrm{C}$ resulted in no CI symptoms at either temperature (Table 2). Plants that were not acclimatized in Expt. 2 and went directly from a greenhouse to $15^{\circ} \mathrm{C}$ had CI that led to severe leaf abscission. It was reported that plants species can be hardened to tolerate chilling temperatures by acclimatizing them at moderately low temperatures (Pike et al., 1990; Wilson and Crawford, 1974). It is not uncommon to measure Phalaenopsis plant temperature being between $10^{\circ} \mathrm{C}$ and $15{ }^{\circ} \mathrm{C}$ after air freight. These could explain the more frequently observed CI symptoms in Phalaenopsis when shipped internationally in the warm summer and early fall than in the cool winter.

McConnell and Sheehan (1978) found that injury symptoms (spotting and pitting) on Phalaenopsis leaves can be induced by exposure to low temperatures of $2^{\circ} \mathrm{C}$ to $7^{\circ} \mathrm{C}$ for $8 \mathrm{~h}$ or less. One or more layers of mesophyll cells between the main veins collapsed and formed an internal horizontal necrotic layer. In this current study, symptoms of CI at higher temperatures $\left(15^{\circ} \mathrm{C}\right.$ to $20{ }^{\circ} \mathrm{C}$ ) always first occur as two large yellow spots at the base of the upper leaves, excluding the youngest, growing leaf (Fig. 1). This is in contrast to that observed by McConnell and Sheehan (1978) at lower temperatures where most of the injury was limited to leaves that were half to three-fourths of mature length. They did not observe symptoms of injury on mature leaves after exposure to temperature between $2^{\circ} \mathrm{C}$ and $7{ }^{\circ} \mathrm{C}$. Perhaps, the 8 -h duration was not long enough to induce chilling or cold injury on the more mature leaves. 
Table 2. Effects of thermal acclimatizing, $10 \mathrm{~d}$ at $25{ }^{\circ} \mathrm{C}$ followed by $10 \mathrm{~d}$ at $20{ }^{\circ} \mathrm{C}$, and air temperature during 10 - $\mathrm{d}$ simulated shipping on subsequent leaf condition and flowering of Phalaenopsis (Atien Kaala Group) 'TSC 22' (Expt. 2).

\begin{tabular}{|c|c|c|c|c|c|c|c|c|}
\hline Storage temp $\left({ }^{\circ} \mathrm{C}\right)$ & $\begin{array}{c}\text { Thermal } \\
\text { acclimatizing }\end{array}$ & Root & $\begin{array}{l}\text { Leaf drop } \\
\text { (no.) }\end{array}$ & Spiking date & Flowering date & $\begin{array}{c}\text { Flower spikes } \\
\text { (no.) }\end{array}$ & $\begin{array}{c}\text { Flower count } \\
\text { (no.) }\end{array}$ & $\begin{array}{c}\text { Flower size } \\
(\mathrm{cm})\end{array}$ \\
\hline Greenhouse $^{z}$ & No & Pot & $0.9 \mathrm{~b}^{\mathrm{x}}$ & 25 Oct. $b$ & 7 Feb. b & $1.9 \mathrm{a}$ & $13.9 \mathrm{ab}$ & $10.9 \mathrm{ab}$ \\
\hline Greenhouse & No & Bare & $1.1 \mathrm{~b}$ & 25 Oct. b & 2 Feb. b & $2.0 \mathrm{a}$ & $15.0 \mathrm{a}$ & $10.1 \mathrm{c}$ \\
\hline & Yes & Bare & $1.1 \mathrm{~b}$ & 1 Nov. b & 9 Feb. b & $1.4 \mathrm{~b}$ & $10.5 \mathrm{~b}$ & $10.5 \mathrm{bc}$ \\
\hline & $\mathrm{No}^{\mathrm{y}}$ & Pot & $2.9 \mathrm{a}$ & 12 Nov. a & 15 Feb. ab & $1.4 \mathrm{~b}$ & $15.1 \mathrm{a}$ & $11.1 \mathrm{ab}$ \\
\hline & $\mathrm{No}^{\mathrm{y}}$ & Bare & $3.0 \mathrm{a}$ & 15 Nov. a & 26 Feb. a & $1.4 \mathrm{~b}$ & $11.5 \mathrm{ab}$ & $10.7 \mathrm{ab}$ \\
\hline Greenhouse & No & Bare & $1.1 \mathrm{a}$ & 25 Oct. b & 2 Feb. ab & $2.0 \mathrm{a}$ & $15.0 \mathrm{ab}$ & $10.1 \mathrm{~b}$ \\
\hline \multirow[t]{4}{*}{20} & Yes & Pot & $0.8 \mathrm{a}$ & 29 Oct. ab & 2 Feb. ab & $1.6 \mathrm{ab}$ & $13.0 \mathrm{~b}$ & $10.9 \mathrm{a}$ \\
\hline & Yes & Bare & $1.0 \mathrm{a}$ & 27 Oct. ab & 28 Jan. b & $1.1 \mathrm{c}$ & $13.5 \mathrm{ab}$ & $10.9 \mathrm{a}$ \\
\hline & $\mathrm{No}^{\mathrm{y}}$ & Pot & $1.0 \mathrm{a}$ & 1 Nov. ab & 6 Feb. ab & $1.9 \mathrm{ab}$ & $18.4 \mathrm{a}$ & $11.3 \mathrm{a}$ \\
\hline & $\mathrm{No}^{\mathrm{y}}$ & Bare & $1.4 \mathrm{a}$ & 3 Nov. a & 9 Feb. a & $1.5 \mathrm{bc}$ & $11.8 \mathrm{~b}$ & $11.0 \mathrm{a}$ \\
\hline Greenhouse & No & Pot & $0.9 \mathrm{a}$ & 25 Oct. b & 7 Feb. ab & $1.9 \mathrm{a}$ & $13.9 \mathrm{~b}$ & $10.9 \mathrm{a}$ \\
\hline & $\mathrm{No}^{\mathrm{y}}$ & Bare & $1.3 \mathrm{a}$ & 31 Oct. a & 11 Feb. a & $1.7 \mathrm{ab}$ & $13.4 \mathrm{~b}$ & $10.9 \mathrm{a}$ \\
\hline Greenhouse & No & Pot & $0.9 \mathrm{~b}$ & 25 Oct. c & 7 Feb. bc & $1.9 \mathrm{a}$ & $13.9 \mathrm{ab}$ & $10.9 \mathrm{a}$ \\
\hline Greenhouse & No & Bare & $1.1 \mathrm{~b}$ & 25 Oct. c & 2 Feb. c & $2.0 \mathrm{a}$ & $15.0 \mathrm{ab}$ & $10.1 \mathrm{~b}$ \\
\hline \multirow[t]{4}{*}{30} & Yes & Pot & $3.4 \mathrm{a}$ & 2 Nov. bc & 5 Feb. bc & $1.6 \mathrm{ab}$ & $12.0 \mathrm{ab}$ & $11.1 \mathrm{a}$ \\
\hline & Yes & Bare & $3.5 \mathrm{a}$ & 28 Oct. bc & 5 Feb. bc & $1.2 \mathrm{c}$ & $12.3 \mathrm{ab}$ & $11.0 \mathrm{a}$ \\
\hline & $\mathrm{No}^{\mathrm{y}}$ & Pot & $3.0 \mathrm{a}$ & 5 Nov. ab & 15 Feb. ab & $1.9 \mathrm{a}$ & $17.4 \mathrm{a}$ & $10.9 \mathrm{a}$ \\
\hline & $\mathrm{No}^{\mathrm{y}}$ & Bare & $3.8 \mathrm{a}$ & 13 Nov. a & 18 Feb. a & $1.4 \mathrm{bc}$ & $10.6 \mathrm{~b}$ & $10.7 \mathrm{a}$ \\
\hline
\end{tabular}

zPlants that remained in the greenhouse.

${ }^{\mathrm{y}}$ Plants taken from a greenhouse and placed directly into storage without thermal acclimatization.

xDuncan's multiple range test was used for mean separation within column and temperature at $P \leq 0.05$.

From the results of this study, bare-root Phalaenopsis orchids should be shipped near $25^{\circ} \mathrm{C}$ during the warm period of the year and between $25^{\circ} \mathrm{C}$ and $15^{\circ} \mathrm{C}$ in the late fall through early spring to avoid CI or heat stress. Results of this study also suggest that vegetative Phalaenopsis plants harvested in the summer and shipped for $4 \mathrm{~d}$ or less may be maintained between $25{ }^{\circ} \mathrm{C}$ and $30{ }^{\circ} \mathrm{C}$. For any longer shipping duration in the summer, Phalaenopsis orchids must be kept at $25^{\circ} \mathrm{C}$ to avoid CI or heat stress. The numerous Phalaenopsis hybrids and clones may have different sensitivity to a given temperature that may result in $\mathrm{CI}$ in some but not the others.

\section{Literature cited}

Christensen, E. 2001. Phalaenopsis-A monograph. Timber Press, Portland, Ore.

Conover, C.A. and R.T. Poole. 1976. Influence of nutrition on yield and chilling injury on Sensevieria. Proc. Fla. State Hort. Soc. 89: 305-307.

Fooshee, W.C. and D.B. McConnell. 1987. Response of Aglaonema 'Silver Queen' to nighttime chilling temperatures. HortScience 22:254-255.

Lee, C.H. and N. Lee. 1991. Characteristics of morphology and anatomy in root and leaf of Phalaenopsis amabilis. J. Chinese Soc. Hort. Sci. 37:237-248.

Lee, N. and G.M. Lin. 1984. Effect of temperature on growth and flowering of Phalaenopsis white hybrid. J. Chinese Soc. Hort. Sci. 30:223-231.

Lee, N. and M.C. Wang. 1997. Changes in mineral composition and carbohydrate contents from juvenile to mature phase in whiteflowered Phalaenopsis plants. J. Chinese Soc. Hort. Sci. 43:295-305.
Lin, G.M. and N. Lee. 1988. Leaf area estimation and the effect of temperature on the growth of Phalaenopsis leaves. J. Chinese Soc. Hort. Sci. 34:73-80.

Marlatt, R.B. 1974. Chilling injury in Sensevieria. HortScience 9: 539-540.

Marousky, D.J. 1980. Chilling injury in Dracaena sanderana and Spathphyllum 'Clevelandii'. HortScience 15:197-198.

McConnell, D.B., D.L. Ingram, C. Groga-Bada, and T.J. Sheehan. 1982. Chilling injury of silvernerve plant. HortScience 17:819-820.

McConnell, D.B. and T.J. Sheehan. 1978. Anatomical aspects of chilling injury to leaves of Phalaenopsis B1. HortScience 13:705-706.

McWilliams, E.L. and C.W. Smith. 1978. Chilling injury in Scindapsus pictus, Aphelandra squarrosa, and Maranta leuconeura. HortScience 13:179-180.

Ota, K., K. Morioka, and Y. Yukio. 1991. Effects of leaf age, inflorescence, temperature, light intensity, and moisture conditions on CAM photosynthesis in Phalaenopsis. J. Jpn. Soc. Hort. Sci. 60:125-132.

Pike, C.S., H.A. Norman, E.C. Kemmerer, D.R. Wessner, C.M. Greenberg, L.J. Kaplan, N.M. Brodsky, and A.A. Ellis. 1990. Effects of acclimation to low temperature and to water stress on photosynthesis and on physical and chemical properties of lipids from thylakoids of cucumber and cotton. Plant Sci. 68:189-196.

Su, V., B.D. Hsu, and W.H. Chen. 2001. The photosynthetic activities of bare root Phalaenopsis during storage. Scientia Hort. 87:311-318.

Tamari, G., J. Tandler, and A. Borochov. 1992. Hardening of clerodendrum to chilling: Chemical treatments and growth at low temperatures. Scientia Hort. 51:285-294.

Treshaw, M. 1970. Environment and plant response. McGraw-Hall, N.Y.

U.S. Dept. of Agr. 2006. Floriculture summary. U.S. Dept. of Agr. Washington, D.C. 
Wang, Y.T. 1987. Effect of temperature, duration, and light during simulated shipping on quality and rooting of croton cuttings. HortScience 22:1301-1302.

Wang, Y.T. 1994. Medium and fertilizer affect the performance of Phalaenopsis orchids during two flowering cycles. HortScience 29:269-271.

Wang, Y.T. 1996. Effect of six fertilizers on vegetative growth and flowering of Phalaenopsis orchids. Scientia Hort. 65:191197.
Wang, Y.T. 1998. Impact of salinity and media on growth and flowering of a hybrid Phalaenopsis orchid. HortScience 33:247-250. Wang, Y.T. 2001. Irradiance levels affect in vitro and greenhouse growth, flowering, and photosynthetic behavior of a hybrid Phalaenopsis orchid. J. Amer. Soc. Hort. Sci. 126:531-536.

Wells, A.W. 1962. Effects of storage temperature and humidity on loss of weight by fruit. U.S. Dept. of Agr. Market. Res. Rpt. 329.

Wilson, J.M. and R.M.M. Crawford. 1974. Leaf fatty-acid content in relation to hardening and chilling injury. J. Expt. Bot. 25:121-131. 